DOI: https://doi.org/10.36910/6775-2524-0560-2021-43-11

УДК 65.011 .56

Макіна Людмила Миколаївна, ст. викладач

https://orcid.org/0000-0003-0735-0743

Троянчук Богдана Віталіївна, студентка

Луцький національний технічний університет

\title{
АНАЛІЗ ІСНУЮЧИХ СИСТЕМ АВТОМАТИЗАЦІї В БДЖІЛЬНИЦТВІ
}

Маркіна Л.М., Троянчук Б.В. Аналіз існуючих систем автоматизації в бджільництві. В статті розглянуто процес ручний процес бджільництва, існуючі на сьогодні системи автоматизації в даному напрямку та зроблені висновки.

Ключові слова: бджільництво, автоматизація, контролери, системи управління.

Маркина Л.Н., Троянчук Б.В. Анализ существующих систем автоматизации в пчеловодстве. В статье рассмотрен процесс ручной процесс пчеловодства, существующие сегодня системы автоматизации в данном направлении и сделаны выводы.

Ключевые слова: пчеловодство, автоматизация, контроллеры, системы управления.

Markina Lyudmila Mykolayivna., Troyanchuk Bohdana Vitaliivna. Analysis of existing automation systems in beekeeping. The article considers the process of manual beekeeping, the existing automation systems in this direction and draws conclusions.

Key words: beekeeping, automation, controllers, control systems.

Постановка наукової проблеми. В сучасному світі бджільництво займає вагоме місце. 95\% бджолярів проводять відкачку меду вручну, що $є$ енерговитратним та трудомістким процесом для людини. Ручне збирання призводить і до наступного ряду проблем:

- на ручне видалення меду витрачається приблизно 90\% часу:

- витрати на будівництво приміщення для вуликів, віджимний пристрій і т.д.;

- вулик може бути пошкоджений в процесі збирання меду;

- турбування частки бджіл, внаслідок чого вони вмирають;

- виймання меду з вуликів здійснюється при сприятливих погодніх умовах;

- поява шкідників та хвороб.[1].

Аналіз досліджень та публікацій. У сфері бджолярства працюють багато винахідників та науковців, які роблять вагомий внесок, як процес так і удосконалення та полегшення збору меду: Седар та Стьюарт Андерсони з патентом «Штучний медовий стільник, вулик і система вуликів», Дронь Юрій Сільвестрович - «Багатокорпусний вулик», Скоромна О.І., Разанова О.П. - «Технологія виробництва продукції бджільництва: навчальний посібник для студентів вищих навчальних закладів». Роботи та здобутки вчених доводять актуальність та важливість даної сфери діяльності.

Мета статті: розглянути методи автоматизації бджільництва. Дослідити оптимізування ручної технології збирання меду.

Постановка завдання:

- узагальнити правила ведення пасіки;

- обгрунтувати важливість параметрів утримування меду;

- продемонструвати етапи технології виробництва меду;

- статистично проаналізувати топ-виробників та експортерів меду у світі;

- виокремити характеристики якості меду;

- проаналізувати переваги та недоліки тих чи інших методів автоматизування;

Об’єкт дослідження: автоматизовані вулики, які вдосконалені датчиками.

Предмет дослідження: ефективність автоматизованих систем бджільництва.

Виклад основного матеріалу досліджень. Бджільництво розвивається за такими напрямами: медотоварний, запилювально-медовий, запилювальний (при вирощуванні культур закритого грунту), розплідницький (виведення маток і формування пакетів бджіл), комплексний. [2].

Пасіки - невелике бджільницьке господарство, що має земельну ділянку з розміщеними на ній тимчасовими або постійними виробничими будівлями. Пасіки можуть бути стаціонарними і кочовими. На пасіках утримують по 100-150 бджолиних сімей. Бджільницькі ферми - складаються 3 декількох пасік. До складу 24 ферми входять бджолині сім’ї, майстерні, зимівники, стільникосховища, складські приміщення та інші споруди.

Пасічницькі комплекси - великі бджільницькі ферми 3 високопродуктивною технологією виробництва і переробки продуктів бджільництва. Застосують ланковий метод обслуговування пасік, 
механізацію основних пасічних робіт, систематичні перевезення бджіл, випуск продукції в розфасованому вигляді, організують спеціальні цехи з необхідним обладнанням.

Міжгосподарські підприємства 3 бджільництва організовують шляхом добровільного об’єднання господарствами пасік, а також частини своїх фінансів, трудових та інших матеріальнотехнічних ресурсів. Організовують переважно у межах одного адміністративного району; вони мають свою садибу, самостійний баланс і $є$ юридичною особою.

Підприємство складається 3 пасік господарств-учасників та окремих цехів 3 виробництва вуликів, розфасовки меду і т. д. За виробничим напрямом пасіки розрізняють:

- медотоварні - призначені для одержання продуктів бджільництва (товарного меду, воску бджолиного, прополісу, маточного молочка, бджолиної отрути, бджолиного обніжжя);

- запилювально-медові, де бджоли використовуються для запилення садів, ягідників i ентомофільних сільськогосподарських культур і для виробництва меду;

- запилювальні - призначені для запилення бджолами культур закритого грунту (у теплицях, парниках тощо);

- репродуктивні (розплідники) - для відтворення бджіл (виведення бджоломаток, виробництва пакетів бджіл і збору маточного молочка);

- племінні - для розмноження, поліпшення і виведення бджіл певної породи, зберігання генофонду бджіл, виведення племінних бджоломаток, виробництва пакетів бджіл і збору маточного молочка;

- карантинні - для витримування бджіл у карантині.

Між рядами має бути проїзд для транспортних засобів шириною 4-6 м. Інтервал між вуликами у рядах 2-4 м. Вулики розміщують на площі з рахунку 20-40 м² на одну бджолину сім'ю і обов'язково фарбують. Бажаними $\epsilon$ синій, жовтий та білий кольори. 3 боку панівних вітрів вирощують високі дерева, а на всій пасіці - плодові та ягідні культури, які створюють затінок для вуликів опівдні, а також використовуються бджолами як орієнтири, щоб не було зльотів. Вулики розміщують задньою чи боковою стінкою до панівного вітру, щоб мінімізувати його вплив на мікроклімат бджолиного гнізда. Напрям льотків вуликів південний, південно-східний, південно-західний. Вулики також бажано розміщувати 3 невеликим нахилом - 2-300 на передню стінку, 3 метою зменшення потрапляння у середину вулика дощу та снігу, а також кращого видалення з нього талого снігу і мертвих бджіл самими бджолами. Вулики розміщують на підставці (металеві рами, дерев’яні стовбці та ін.), висота якої повинна бути у межах 30-40 см. Пасіки можуть бути стаціонарними (100-120 бджолиних сімей) i кочовими. Для пасічного точка не можна обирати місце на трасі льоту бджіл з інших пасік і не створювати такої перешкоди для сусідніх. Вранішня тінь затримує початок льотної роботи сімей, тому 26 вибирають місце, яке вже 3 досвітку обігрівається сонцем, а вдень затінюється кроною дерев.

Територія пасіки також повинна бути огородженою (висота огорожі 2 м), мати невеликий нахил, 3 метою усунення застоювання опадів. На території пасіки повинні бути приміщення для переробки воскової сировини, зберігання продукції, тари й матеріалів, для виготовлення та ремонту вуликів, можлива наявність будинку пасічника, зимівника для бджіл, приміщення для відкачування меду, приміщення для зберігання стільників та контрольний вулик. Не бажано розміщувати пасіку біля високовольтних ліній електропередач (100 м), житлових приміщень, дитячих садків та шкіл (100 м), корівників (300 м), свинарників (500-800 м). [3].

Зимою у бджолянику підтримують параметри мікроклімату, температура у гнізді $+24-28^{\circ} \mathrm{C}$, відносна вологість 74-80\%, вміст кисню $12-14 \%$, вуглекислоти до 3-4\%. Навесні сім'ї бджіл виносять із зимівника для обльоту при зовнішній температурі повітря не нижче $12^{\circ} \mathrm{C}$. Температура повітря у гнізді 282 повинна бути $24-26^{\circ} \mathrm{C}$, відносна вологість $72-85 \%$, вміст кисню $15-17 \%$, вуглекислоти $1,7-$ 2,3\%.[4]. Всі ці параметри важливі для подальшого існування бджіл та кращих показників збору меду.

Одержання відцентрованого меду здійснюється наступним чином:

$\checkmark$ відбирання стільників із вулика, розпечатування стільників за допомогою пасічницького ножа,

$\checkmark$ відкачування меду стільників за допомогою медогонки,

$\checkmark$ зливання меду у ємкості, проціджування або фільтрування,

$\checkmark$ відстоювання за температурою $20^{\circ} \mathrm{C}$, розливання у тару, пакування.

За статистикою бази даних «NationMaster» топ-5 країн з виробництва натурального меду в 2019 році: на 1 місці - Китай (497,286 тонн), 2-ому - Туреччина (1 17,044 тонн), 3-ьому - Іран (78,553 тонн), 4-ому - Аргентина $(78,188), 5$ - Україна (69,491 тонн).

За статистичними даними «World's Top Exports» топ-5 країн експортерів меду за 2019 рік: на 1 місці - Китай (11,8\% експортованого натурального меду, 253,3 млн.дол.США), 2-ому - Нова 
Зеландія (11,5\%, 228,8 млн.дол.), 3-ьому - Аргентина (7,4\%, 146,7 млн.дол.), 4-ому - Німеччина (6,6\%, 131,5 млн.дол.) , 5 - Україна (5,7\%, 113,3 млн.дол.).

Бджолиний мед містить багато цукрів, зольних елементів, ферментів, органічних кислот, азотистих сполук, вітамінів, ароматичних, біологічно активних та інших речовин у складі сухої речовини. Вміст їх становить 4/5 загальної маси меду. Водність більшості сортів зрілого меду становить близько $18 \%$, проте залежно від місцевості його збирання вона часто коливається від 15 до $21 \%$. Незрілий мед містить води $22 \%$ і більше.

Високоякісні сорти меду містять близько 75 \% простих цукрів (глюкози, як правило, близько $35 \%$, фруктози 40 \% ). Співвідношення їх визначає фізичні якості меду: при збільшенні вмісту глюкози підвищується його кристалізаційна здатність, а при збільшенні вмісту фруктози він стає солодшим на смак і більш гігроскопічним.

Сахарози в зрілому меді дуже мало - в середньому від 1,3 до 5 \% . Вміст азотистих сполук у меді становить у середньому $0,4 \%$. Мінеральних речовин (золи) у меді в середньому $0,17 \%$. Якісний мед містить інвертазу, амілазу, каталазу, пероксидазу та інші ферменти. Для оцінки якості меду визначають його діастазне число, яке у більшості сортів меду, за даними Української дослідної станції бджільництва, становить 11,5-25. [2].

У зв'язку з розвитком науково-технічного прогресу, що передбачає впровадження у всі сфери діяльності засобів автоматизації та цифрових технологій, не оминуло це бджолярство. В ході дослідження даного виду господарства були виявлені проблеми, які саме можна вирішити за допомогою використання різноманітних датчиків та мікроконтролерів. Під автоматизацією розуміють

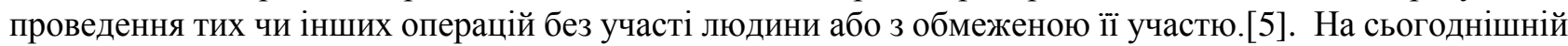
день вже відомі системи автоматизації вуликів та бджільництва загалом., серед яких $[6,7,8,9]$ :

1. В університеті Панамерикана. Факультет Інженерії. Августо Роден, Едуардо Лопес-Тагле, Едуардо Сікейрос, Хірам Понсе запропонували електронний вулик, який автоматично збирає мед, регулює температуру всередині вулика і розподіляє їжу для бджіл.

У роботі автори досліджують і вивчають поведінку медоносних бджіл. Зокрема, вони вели відеоспостереження та визначали закономірності бджіл. Розробили бездротову сенсорну мережу для контролю вуликів всередині та зовні, і встановили, що міграція бджіл обумовлена зміною температури всередині вуликів. Обстежили різні раніше здійснені методи моніторингу, такі як: вимірювання температури, вологості та газів, а також звук, вібрація та відео. Отже, стабільні значення температури $\epsilon$ найбільш оптимальними умовами для бджіл.

Седар та Стьюарт Андерсони сконструювали штучний стільник, який дозволяє видаляти мед, не виймаючи стільник з вулика. У цьому патенті розглядаються рухомі клітини, які дефазують стільник, тому мед стікає вниз. Перевагою є безпечність для бджіл, однак, недоліком є те, що він ручний, адже до нього не прикріплені електронні пристрої.

Запропоновано, щоб вулик мав три компоненти: стільник, в якому бджоли виробляють мед, контейнер для зберігання, призначений для автоматизації харчових ресурсів, та електронний модуль, що містить всю електроніку та комп'ютер пристроїв.

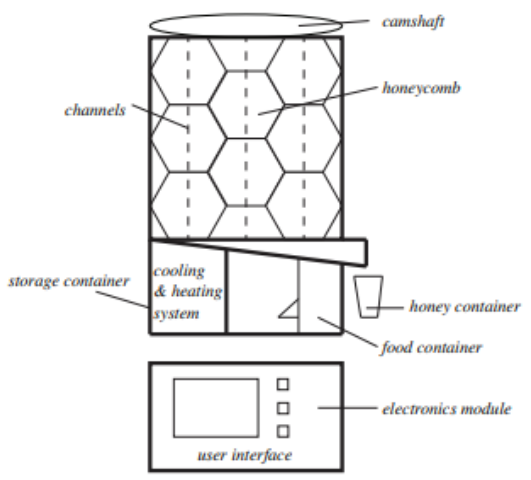

Рисунок 1. Схема розумного вулика.

На рисунку 1 представлена схема запропонованого автоматизованого вулика.

Стільник - це сітка, створена на основі штучного стільника [6], сітка складається з каналів, які можуть рухатись вгору та вниз для фазування та дефазації порожнин сітки. Ці канали автоматизовані за допомогою механізму у верхній частині сітки (рис. 1). 
Кожен канал прикріплений до розподільного валу, який обертається залежно від приводу. Коли сітка дефазована, видобуток меду відбувається самопливом, а також ця процедура нешкідлива для бджіл. Важливо зауважити, що як тільки мед потрапляє на дно стільника, він потрапляє в один канал, який прямує безпосередньо до контейнера для меду. Цей контейнер також автоматизований за допомогою датчиків.

У верхній частині контейнера прикріплений один датчик, який автоматично визначає, чи ємність заповнена. Коли настає остання умова, сітка закривається, тому мед перестає стікати вниз. Також встановлюється сигнал тривоги, який повідомляє пасічнику про те, що ємність 3 медом заповнена і готова до зміни.

3 іншого боку, стільник забезпечений системою регулювання температури. Він складається 3 датчика температури, системи охолодження, системи опалення та мікроконтролера. Система контролю спрямована на регулювання внутрішньої температури стільникового середовища між $25^{\circ} \mathrm{C}$ i $30^{\circ} \mathrm{C}$, на основі досліджень, пов'язаних з температурними умовами, про які повідомляється в [7]. Контролер запускає систему охолодження та зупиняє систему опалення, коли досягається верхня гранична контрольна температура.

Контейнер для зберігання є обмеженим доступом для бджіл, який розділений на дві секції. Перший розділ розглядає обладнання для температурної системи, а другий розділ передбачає продовольчі ресурси для бджіл, коли це потрібно.

По-перше, щоб системи охолодження та опалення не впливали на структуру бджіл, ці системи розташовані з одного боку контейнера для зберігання. Тепловий вплив цих систем непрямий, тому бджоли ніколи не контактують 3 ними.

По-друге, якщо цикли врожаю не є регулярними (тобто відсутні продовольчі ресурси), тоді контейнер для зберігання відкривається для бджіл. Вони можуть подорожувати з стільників до цієї ємності. На стороні харчових ресурсів контейнера автоматизований клапан забезпечує достатню кількість їжі для бджіл.

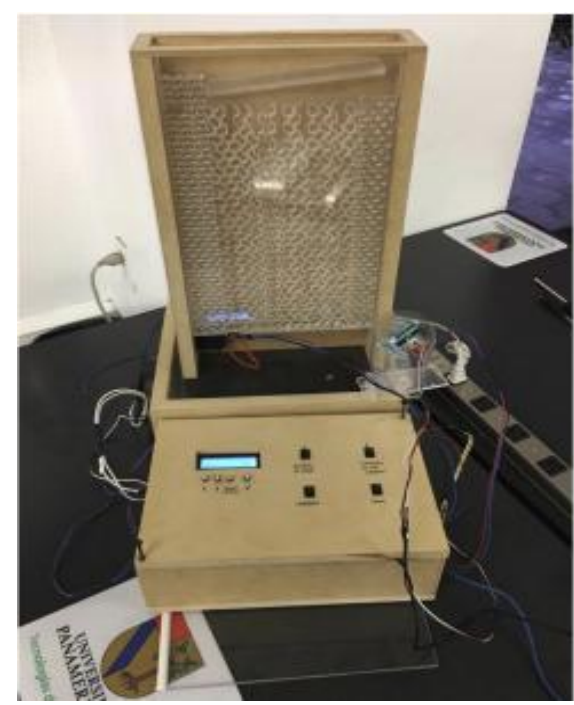

Рисунок 2. Реалізація прототипу автоматизованого вулика.

Впровадження прототипу. Для підтвердження пропозиції було розроблено функціональний прототип, як показано на рис.2. Це масштабований прототип, і для політики щодо тварин на даному етапі проекту бджоли не розглядалися. Для соти виготовили одну рамку (замість звичайних 10 рам), щоб довести дефазацію сітки. Для системи регулювання температури система опалення була реалізована 3 підсвічуванням, а система охолодження - 3 невеликим вентилятором, а використовувався датчик температури LM35. Рис.2. Прототип реалізації автоматизованого вулика. для цілей моніторингу. 


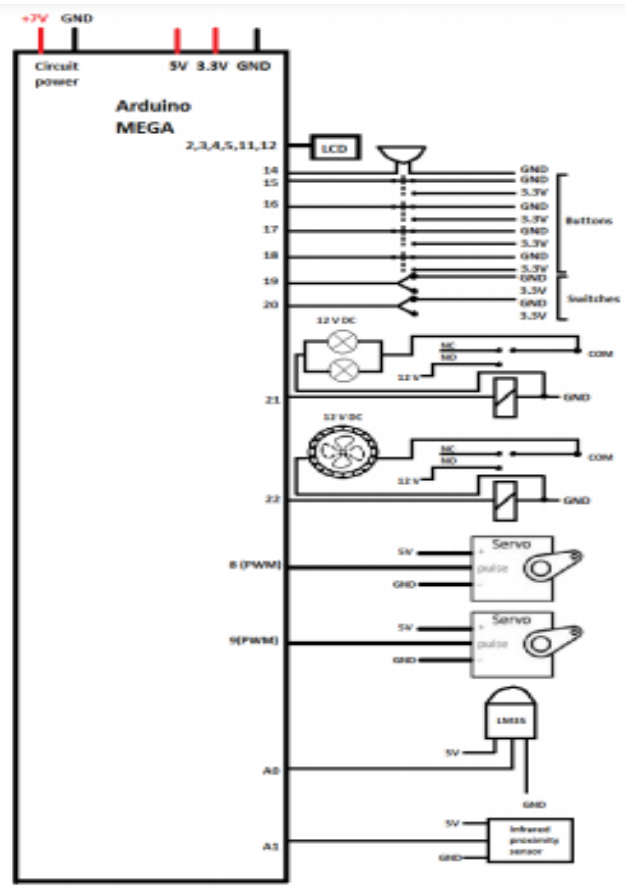

Рисунок 3. Схема електричної та електронної системи автоматизованого вулика.

Як мікроконтролер повної системи використовувався Arduino MEGA. Електрична та електронна система автоматизованого вулика показана на рис.3.

Як зазначалося, користувальницький інтерфейс був реалізований за допомогою ПК-дисплея, матриці кнопок та перемикачів. Цей інтерфейс має на меті вибрати температурний режим і вручну увімкнути / вимкнути світло та вентилятор.

Крім того, дві лампочки, що використовуються для системи опалення та невеликий вентилятор для системи охолодження. Також були підключені два датчики: датчик температури LM35 та інфрачервоний датчик наближення Sharp GP2D12 для вимірювання рівня меду в контейнері. Два серводвигуни були прикріплені до плати Arduino для управління розподільним валом стільника та доступу до продовольчих ресурсів у контейнері для зберігання.

2. На I Міжнародній науково-практичній конференції 3 бджільництва, апітерапії та медоваріння: «Сучасне бджільництво: проблеми та глобальні виклики» Нєдов Роман, мешканець міста Дніпро, представився програмістом, а не бджолярем. Він розповів про свою ідею - «Автоматизацію контролю за вагою пасіки». Для наочності продемонстрував електронні ваги у вигляді прямокутної дошки зі чотирма датчиками по кутам, живлення подається від акумулятора (без додаткового живл. працює до двох тижнів). Прилад знімає показання ваги з вулика. Кожен датчик розрахований на 50 кг, всього можливо зважити 200 кг, допустима похибка \pm 25 грам. До датчиків підключається блок мікроелектроніки на 5 В. Додається GSM (фр. Groupe Spécial Mobile) модуль, яка має змогу відправляти зібрані дані (наприклад: вагу, температуру, вологість) на телефон у виді повідомлення. Роман підкреслив, що є додаткові переваги: по-перше: датчик можна поставити на контроль верхньої кришки, по-друге: додати модуль GPS (англ. Global Positioning System) та передавати координати розташування пасіки, в разі пї переміщення.

Контроль за вагою предстає перед користувачами сигналізацією при різкій змінні ваги, яка увідомляє повідомленням на смартфоні. Створений веб-сайт, в якому пасічник вводить логін та пароль на якому є всі дані з датчиків, параметри можна змінювати (частота оновлення даних).

Після викачування меду в сезон, пасіка переходить на зимування. Під час якої, необхідний більший контроль за показниками, а також відстеження рою. В якій частині вулика температура тепліша чи холодніша, і в яку сторону його розвернути.[8].

3.Автоматизація електропривода медогонки з двигуном постійного струму. В сучасних умовах господарювання у 95\% випадків бджолярі здійснюють відкачку меду з використанням власної фізичної сили для приводу медогонки. Існуючі електроприводи медогонок неефективні і призводять до неякісного відкачування меду.

Вибираємо центрифугу «Медогонка РЕП» на чотири рамки, з оборотно-хордовими касетами, ремінним приводом та баком 3 нержавіючої сталі. Визначаємо фізико-хімічні параметри меду для подальшого визначення динамічних характеристик і нижньої межі діапазону регулювання частоти 
обертання (температуру, вологість, в'язкість). Для меду вологістю $18,5 \%$ i температура $30^{\circ} \mathrm{C}$ встановлені наступні діапазони частот обертання по етапах: 1-ий - від 80 до 90 об/хв; 2-ий - від 100 до 120 об/хв; 3-ий - від 160 до 180 об/хв. Для 4-х рамкової медогонки з нержавіючої сталі та автоматичними рамками «Дадан» процес відкачування меду за вибраною медогонкою відбувається в три етапи. 1-ий - відкачування, на малій швидкості першої сторони рамки, через заданий проміжок часу двигун зупиняється, вмикається реверс, касети повертаються; 2-ий - відкачування 3 другої сторони рамки, спочатку на малій швидкості, а потім без зупинки на високій, зупинка; 3-ій вмикається реверс, касети перевертаються для відкачування решти меду та повної осушки першої сторони на високій швидкості. Двигун зупиняється за допомогою динамічного гальмування.

На кафедрі автоматизованих електромеханічних систем була розроблена електрична схема керування електроприводом медогонки 3 двигуном постійного струму, яка передбачає ручний та автоматичний режим роботи. [9].

Висновки та перспективи подальшого дослідження. Після проведеного огляду існуючих систем автоматизації, можна зробити наступні висновки:

1. Два перших рішення реалізовують автоматизацію безпосередньо вуликів, які мають наступні переваг: контролювати параметри мікроклімату можна буквально 3 телефону, відсутній контакт з вуликами, зменшення втрат бджіл, а також вартість контролера, який забезпечує функціонування даних систем автоматизації, що теж відіграє важливу роль при масовому використанні.

2. Третій варіант автоматизації демонструє способу керування електроприводом центрифуги, що підвищує продуктивність пасіки та зменшує ймовірність пошкодження рамки.

Кожна система автоматизації також має і недоліки: догляд за станом датчиків, терміни придатності та точність виміру, не компетентність людини, яка контролює процес. Врахувавши всі переваги та недоліки існуючих систем автоматизації ми прийшли до висновку, що для забезпечення ефективної роботи та збільшення продуктивності пасіки, необхідно розробити таку систему керування, яка б компенсувала всі недоліки розглянутих систем з застосуванням більш нових методів, а саме елементи нечіткої логіки. Даний напрямок дозволить більш детально проаналізувати, дослідити та усунути наявні проблеми.

\section{Список бібліографічного опису:}

1. UA 111009, МПК (2016.01), А01K 47/04 (2006.01). Штучний медовий стільник, вулик і система вуликів. Публікація відомостей про видачу патенту: 10.03.2016, Бюл.№ 5

2. Мегедь О.Г., Поліщук В.П. Бджільництво. К.: Вища школа. 1987. 336 с., ст.302, ст.185-186.

3. Скоромна О.І., Разанова О.П. Технологія виробництва продукції бджільництва: навчальний посібник для студентів вищих навчальних закладів. Вінниця, 2020. 408 с., ст.23-26.

4. Інструкція щодо попередження та ліквідації хвороб і отруєнь бджіл розроблена відповідно до статті 12 Закону України “Про ветеринарну медицину”, Закону України “Про бджільництво”, Положення про Державний департамент ветеринарної медицини, затвердженого постановою Кабінету Міністрів України від 17 листопада 1997 року № 1277 п.2.

5. Попович М.Г., Ковальчук О.В. Теорія автоматичного керування: Підручник.-К.:Либідь, 1997.-544c. ст.5.

6. Лисиченко М.Л., Хандола Ю.М., Середа А.І., Назаренко О.Ю. Автоматизація електропривода медогонки 3 двигуном постійного струму. Науковий вісник ТДАТУ. Харків: В7, Т1. ст.23-29 .

\section{References.}

1. C. Anderson and S. Anderson, “Apiculture (us patent)," USPatent Number 20140370781 A1, Application, 2014.

2. D. S. Kridi, C. G. N. de Carvalho, and D. G. Gomes, "Appli-cation of wireless sensor networks for beehive monitoring andin-hive thermal patterns detection," Computers and Electronicsin Agriculture, vol. 127, no. 2016, pp. 221 - 235 , 2016.

3. You-tube канал: Intelligent BEEKEEPER https://www.youtube.com/watch?v=2O2CKEDRsVQ\&t=5s. 